\title{
KAMIL SZYMAŃSKI
}

(Lublin)

\section{TRANSHUMANIZM: UTOPIA CZY EKSTROPIA?}

Większość ludzi marzy o życiu w spokoju i dobrobycie. Potrzeba zapewnienia bezpieczeństwa oraz dobrobytu silnie oddziaływała na kształt wielu systemów społecznych choćby Thomasa Hobbes'a czy Johna Locke'a. I choć do tej pory nie udało się wytworzyć takiego społecznego stanu, to ludzie wciąż mają nadzieje na to, że pewnego dnia ziści się wizja doskonałego społeczeństwa. Z tego powodu wielu myślicieli starało się stworzyć system społeczny urzeczywistniający równość, tolerancję i dobro ogółu, a nie tylko uprzywilejowanych grup. Z tego też powodu zaczęły pojawiać się utopie.

Na wstępie trzeba podkreślić, że historycznie pojęcie „utopia” ulegało znacznym przekształceniom, stawało się coraz bardziej rozbudowane, stając się przy okazji coraz bardziej ogólne, nieczytelne i problematyczne. Dlatego, nim przejdę do analizy tego, czym jest ekstropia, potrzebne będzie zdefiniowanie pojęcia utopii. Warto dodać, że utopię można rozpatrywać jako konstrukt teoretyczny (tzn. jako koncepcję na temat pewnego stanu rzeczy lub krytykę zastanej rzeczywistości) albo jako pewien realizowalny lub zaistniały stan społeczny (udoskonalenie rzeczywistości społecznej). Zawarte w tym tekście analizy będą dotyczyły głównie pewnego „realnego stanu”, który można określić mianem utopii technologicznej, jak również samej definicji i rozumienia tego pojęcia.

Termin „utopia” pochodzi z łacińskiego tytułu dzieła Tomasza Morusa, Libellus aureus nec minus salutaris quam festivus de optimo Reipublicae statu de que nova insula Utopia (Ksiażeczka zaiste złota i niemniej pożyteczna jak przyjemna o najlepszym ustroju państwa i nieznanej dotad wyspie Utopii), powstałego w 1516 roku. Morus przedstawił w niej losy szczęśliwej wyspy, pozbawionej nędzy, wyzysku, kłamstwa i przemocy, nietolerancji, wyspy bez zawiści i złości, bez 
próżniactwa i pracy ponad siły. Było to miejsce równocześnie i doskonałe, i nierealne. Te dwa sensy są właśnie zawarte w etymologii słowa „utopia”. „Topia” oznacza miejsce, zaś przedrostek „u” może odnosić się zarówno do greckiego „eu” jak i „ou”. Eutopia oznacza dobre miejsce, outopia - miejsce, którego nie ma ${ }^{1}$. Utopia Morusa łączy więc w sobie cechy nierealności i doskonałości, przysługujące miejscu wyobrażonemu, wykreowanemu przez autora. Jak twierdzi J. Szacki, utopie powstawały często jako krytyka ówczesnego porządku świata (jak dzieło Morusa $^{2}$ ), jako program działania lub ostrzeżenie (antyutopie Huxleya i Orwella $\left.{ }^{3}\right)^{4}$.

Szacki podkreśla również, że o utopijnym charakterze dzieła nie decyduje forma literacka, lecz określony sposób myślenia ${ }^{5}$, który wiąże się z kreowaniem rzeczywistości w sposób skrajny - zarówno w sposób pozytywny w utopiach, jak i w sposób skrajnie negatywny w antyutopiach. Dodatkowo Szacki dokonuje podziału utopii w zależności od ich budowy. Możemy mówić o: utopii miejsca - jako szczęśliwe „gdzieś", pewne utopijne miejsce umiejscowione w pewnej przestrzeni; utopii czasu - szczęśliwe miejsce gdzieś w przyszłości lub przeszłości; utopii ładu wiecznego - tj. budowy utopii w oparciu o wartości wyznawane przez „twórcę" danej utopii; utopii zakonu - jako miejsca odosobnienia, budowy nowego świata oderwanego od dotychczasowego; utopii polityki - jako budowa doskonałego ładu społeczno-politycznego ${ }^{6}$. Utopie jako takie mogą realizować się na różne sposoby, mogą zaistnieć zarówno w czasie, jak i przestrzeni, oraz dotykać różnych aspektów życia ludzkiego - społecznego, polityki, ekonomii itp.

W XX wieku inną definicję utopii zaproponował Karl Mannheim. Przywołuję ją dlatego, że takie współczesne rozumienie utopii zdecydowanie rozszerza jej sens wcześniejszy. Ważne jest także, że Mannheim bada zależność pomiędzy myśleniem ideologicznym i utopijnym, wskazując, że różnicującym kryterium jest możliwość realizacji takiego myślenia $\mathrm{w}$ świecie, a fakt ten będzie kluczowy w analizie transhumanizmu.

Analizując sens utopii, Mannheim zestawia ją z ideologią. Różnicuje je możliwość ,zaistnienia w rzeczywistości”. Ideologie oraz utopie są transcendentne wobec rzeczywistości, jednak to utopie mają szansę na realizację w świecie ${ }^{7}$. Ideologie, według Mannheima, nie zostaną zrealizowane nigdy, choć są stale obecne

1 J. Szacki, Spotkania z utopia, Sic!, Warszawa 2000, s. 12.

2 Por. T. Morus, Utopia, przeł. Barbara Smoczyńska, Daimonion, Lublin 1993.

3 Por. A. Huxley, Nowy wspaniaty świat, przeł. Bogdan Baran, Warszawskie Wydawnictwo Literackie Muza, Warszawa 2014; G. Orwell, Rok 1984, przeł. Tomasz Mirkowicz, Warszawskie Wydawnictwo Literackie Muza, Warszawa 2013.

4 Por. J. Szacki, Spotkania z utopia..., wyd. cyt., s. 12-15.

5 Tamże, s. 15.

6 Tamże, s. 65-171.

7 K. Mannheim, Ideologia i utopia, przeł. Jan Miziński, Test, Lublin 1992, s. 161. 
w świadomości „uprzywilejowanej” grupy osób w danej rzeczywistości społecznej. O utopiach Mannheim pisze następująco: „Utopie również są transcendentne wobec rzeczywistości, gdyż one także nadają działaniu orientację na elementy, których realizowana w tym samym czasie rzeczywistość nie zawiera; nie są one jednak ideologiami, czy też nie są nimi o tyle i w takiej mierze, o ile udaje im się transformować istniejącą historyczną rzeczywistość poprzez przeciwdziałanie jej w kierunku własnych wyobrażeń" ${ }^{8}$. Oznacza to, że zarówno utopie, jak i ideologie, pozostają transcendentne wobec świata oraz są nakierowane na pewne nieobecne w świecie idee. Ideologia może stać się utopią, jeśli przejdzie w stan realizacji. Utopia zaś nie stanie się ideologią, ponieważ jest już realizowana a więc nie może wrócić do stanu transcendencji. Mannheim pisze: „Dopiero z chwilą, gdy określone grupy ludzi włączyły te obietnice w swoje działanie i próbowały je urzeczywistnić, ideologie te stały się utopiami" ${ }^{9}$.

Ideologia może się również wiązać z tendencją do utrzymania zastanego stanu rzeczy, tj. układu, w którym żyje „uprzywilejowana” grupa. Dodatkowo, myślenie ideologiczne jest raczej związane z grupami, które „dominują” w danej rzeczywistości, podczas gdy myślenie utopijne jest związane z mniejszościami, sprzeciwiającymi się zastanemu porządkowi i pragnącymi jego zmiany. Jeśli dana utopia nie jest realizowana, lecz pozostaje transcendentna wobec świata, to pozostaje jedynie ideologią (w rozumieniu Mannheima). Określanie tego, co jest utopią, pozostaje jednak uzależnione od tego, kto wygłasza sąd o utopii. Osoby społecznie uprzywilejowane będą nazywały utopijnymi pomysły mniejszości, starając się utrzymać stan, w którym pozostaną grupą dominującą. Zmiana może spowodować odwrócenie istniejącego porządku społecznego, mniejszość może przez to uzyskać władzę, a grupa uprzywilejowana - ją stracić.

Świadomość utopijna to świadomość potrzeby zmiany i jej urzeczywistnienia. Utopie według Mannheima są w ciągłym procesie realizacji ${ }^{10}$. Oznacza to, że wszelkie postulowane zmiany zastanej rzeczywistości można określać mianem utopii. Ideologie natomiast nie są realizowane, legitymizują zastany stan rzeczy i nie zmieniają go. Dlatego ideologie ukierunkowane są na przeszłość, podczas gdy utopie kierują się w stronę przyszłości ${ }^{11}$. Morus napisał swą Utopie jako krytykę zastanego stanu rzeczy. Gdyby rozpoczął realizację swej wizji, stałaby się ona również utopią w rozumieniu Mannheima. Ponieważ nie była realizowana, pozostała jedynie ideologią.

\footnotetext{
8 Tamże, s. 162.

9 Tamże, s. 160.

10 P. Ricœur, Lectures on Ideology and Utopia, Columbia University Press, New York 1986, s. 273 .

11 Tamże.
} 
Trzecia definicja utopii pochodzi od Georga Pichta. Zgodnie z jego definicją, znaczny wpływ na powstawanie utopii wywiera technologia. Fakt ten ma zaś kluczowe znaczenie w kontekście tytułowej ekstropii. Definiując utopię, Picht wychodzi od spostrzeżenia, że pierwsze utopie powstawały jako krytyki ówczesnego systemu społeczno-politycznego. Twierdzi jednak, że utopie mogą zostać zrealizowane. Skoro są krytyką zastanego stanu rzeczy, to mają również potencjał, by się urzeczywistnić i przekształcić rzeczywistość - zgodnie z definicją utopii formułowaną przez Mannheima ${ }^{12}$. Tak więc Picht nie tylko korzysta z tradycyjnej definicji utopii, lecz wykorzystuje również pewne wątki zaproponowane przez Mannheima. Picht podkreśla przede wszystkim znaczenie, jakie dla przemian zachodzących w świecie ma rozwój technologiczno-naukowy; pisze następująco: „[...] bez Tomasza Morusa nie do pomyślenia jest Bacon...” 13. Dlatego opierając się na dorobku rozwoju techniczno-naukowego oraz szkicowym opisie obecnego stanu rzeczywistości, Picht definiuje utopię jako racjonalny program przetrwania gatunku ludzkiego. „W drugiej połowie XX wieku pozostała już tylko jedna racjonalna utopia; jasno ukazuje to pozytywny sens modelu MIT jako konstrukcji typu idealnego ${ }^{14}$. Jedyną racjonalną utopią byłby taki stan świata, w którym zagwarantowana jest biologiczna egzystencja gatunku Człowiek. W odróżnieniu od dawniejszych utopii, ta utopia nie jest igraniem możliwościami, z których można by zrezygnować" ${ }^{15}$. Picht definiuje utopię jako ratowanie gatunku ludzkiego przed ewentualną zagładą, która może nastąpić ze względu na niemożliwość wyżywienia ogromnej ilości osób, konflikt nuklearny czy wyeksploatowanie Ziemi z surowców, zamykające możliwość dalszego rozwoju. Definicja Pichta jest jednak zbyt szeroka, ponieważ każda zmiana w świecie, która poprawia warunki ludzkiego życia, może zostać uznana za utopię, przez co definicja traci swoją efektywność.

Z kolei „ekstropia” jest pojęciem występującym w współczesnym transhumanizmie. Transhumanizm to koncepcja postulująca wykorzystanie nauki oraz techniki w celu przezwyciężenia biologicznych ograniczeń człowieka. Skutkiem tego ma być pojawienie się postczłowieka - człowieka „ulepszonego” w takich wymiarach jak: długość życia, zdolności kognitywne, zdolności emocjonalne ${ }^{16}$. Twórca współczesnego sensu pojęcia „transhumanizm” - Max More - twierdzi, że dzięki

12 Por. G. Picht, Technika $i$ utopia [w:] Tenże, Odwaga utopii, przeł. Krzysztof Maurin, Krzysztof Michalski, Krzysztof Wolicki, Państwowy Instytut Wydawniczy, Warszawa 1981, ss. 188-208.

13 Tamże, s. 208.

14 Picht odnosi się do raportu MIT pt. Granice wzrostu z 1972 r. w którym dokonywana jest analiza pomiędzy stanem demografii a zużyciem surowców.

15 G. Picht, Technika $i$ utopia..., wyd. cyt., s. 208.

16 Por. K. Szymański, Tranhsumanizm, „Kultura i Wartości”, 13 (2015), ss. 133-152. 
wykorzystaniu osiągnieć nauki w najbliższej przyszłości (szacunkowo - w połowie naszego stulecia lub pod jego koniec ${ }^{17}$ ) ludzie będą w stanie przezwyciężyć większość problemów, z którymi obecnie się zmagają. Stanie się to jednak dopiero wtedy, gdy człowiek przerodzi się w postczłowieka ${ }^{18}$ - istotę, której możliwości będą przekraczały zdolności współczesnych ludzi. Wraz z przemianą jednostkowego człowieka, zmianie ulegnie również posthumanistyczne społeczeństwo.

Przemiany transhumanistyczne mają się opierać na wykorzystaniu rezultatów takich nauk jak medycyna, biotechnologia, bioinżynieria, nanotechnologia czy neuronauki ${ }^{19}$. Współczesne odkrycia naukowe oraz ich dynamiczny rozwój każą transhumanistom myśleć, że w postępie w dziedzinie techniki oraz nauki nie istnieją żadne granice; sądzą więc, że dzięki nauce przyszły człowiek osiągnie „doskonałość". Już dzisiaj trwają eksperymenty nad wykorzystaniem zaawansowanej techniki w celu poprawy ludzkiego życia: medycyna jest w stanie przywracać sprawność osobom, które ucierpiały w wypadkach, wykorzystujac sztuczne kończyny drukowane w drukarkach 3D ${ }^{20}$. Aparatura medyczna jest w stanie podtrzymywać przez długi czas życie osób ze stwierdzoną śmiercią mózgową. Transhumaniści sądzą, że w niedalekiej przyszłości ludzkość będzie w stanie przekroczyć granice swych biologicznych ograniczeń, takich jak zbyt krótkie życie, fizyczne i psychiczne stany chorobowe, podatność na obrażenia.

Postczłowiek, o którym piszą transhumaniści, ma być kolejnym etapem (lecz nie ostatnim) w ewolucji człowieka. Po pierwsze, będzie to istota o znacznie wydłużonym czasie życia. Dla transhumanistów najważniejszą wartością jest życie ${ }^{21}$, stąd ich sprzeciw wobec śmiertelności oraz starzenia się. Trzeba przy tym podkreślić, że nie ma dla nich znaczenia, na jakiej drodze to się dokona. Może to na przykład nastąpić poprzez modyfikacje ludzkiego DNA, poprzez transfer świadomości do cyfrowego nośnika czy też poprzez technologiczne modyfikacje organizmu

17 N. Bostrom, The Transhumanist FAQ, Faculty of Philosophy, Oxford University 2003, s. 50. Tekst dostępny pod adresem: http://www.nickbostrom.com/views/transhumanist.pdf [dostęp: 24.05.2015].

18 N. Bostrom, Transhumanist Values [w:] Ethical Issues for the Twenty-first Century, red. Frederick Adams, Philosophy Documentation Center, Charlottesville 2005, ss. 3-14.

19 M. More, The Philosophy of Transhumanism [w:] The Transhumanist Reader: Classical and Contemporary Essays on the Science, Technology, and Philosophy of the Human Future, red. Max More, Natasha Vita-More, Wiley-Blackwell, Chichester UK 2013, s. 16.

20 Por. np. Les Baugh - mężczyzna który 40 lat temu w wypadku stracił obie ręce. Obecnie do jego ciała przymocowane są sztuczne kończyny, które pozwalają mu na samodzielne funkcjonowanie. http://www.businessinsider.com/les-baugh-is-the-first-person-with-two-mind-controlledrobotic-arms-2014-12 [dostęp: 24.05.2015]. Prezentacja protez nóg, które pozwalają powrócić do pełnej sprawności osób, które ucierpiały w wypadkach. http://www.kurzweilai.net/roboticleg-prosthetic-allows-amputees-to-walk-normally [dostęp: 24.05.2015].

21 M. More, A Letter to Mother Nature [w:] The Transhumanist Reader..., wyd. cyt., s. 344. 
ludzkiego. Skoro dłuższe życie jest dla nich zasadą nadrzędną, to nie powinno dziwić, że niektórzy transhumaniści regularnie ćwiczą i dbają o zdrowie, by dożyć czasów, gdy będą mogli przedłużyć własne życie ${ }^{22}$.

Kolejne zmiany, które mają się dokonać w postczłowieku, to zwiększenie ilości jego zmysłów oraz jego zdolności intelektualnych ${ }^{23}$. Kevin Warwick, nazywany pierwszym cyborgiem, przeprowadził na sobie eksperyment, w którym elektroniczny implant dostarczał informacji do jego mózgu za pomocą echolokacji ${ }^{24}$. Był to prawdopodobnie pierwszy człowiek (lub jeden z pierwszych), który posiadł dodatkowy zmysł niedostępny innym ludziom. Był on w stanie, niczym nietoperz, orientować się w rozkładzie pomieszczenia bez używania wzroku. Może to skłaniać do prognozy, że dzięki podobnym wynalazkom ludzie w przyszłości będą w stanie posiadać inne, niedostępne im obecnie zmysły, co prawdopodobnie wpłynie na ich percepcje oraz sposób myślenia o świecie.

Nick Bostrom sądzi, że używając rozwiązań technicznych, będziemy mogli wspomagać działanie naszego mózgu w zakresie analizowania i zapamiętywaniu informacji: „[...] tak samo jak w wypadku naczelnych, nasze zdolności kognitywne mogą nie dopuszczać całej warstwy zrozumienia i aktywności intelektualnej [...]. Niemożliwość, do której się odnoszę, jest podobna do tej, która sprawia, że współcześni ludzi nie potrafią sobie wyobrazić dwustuwymiarowej hiperprzestrzeni lub przeczytania z dokładnym zapamiętaniem i zrozumieniem każdej książki z biblioteki Kongresu. Działania te są dla nas niemożliwe, ponieważ zwyczajnie brakuje nam zasobów umysłowych" ${ }^{25}$. Bostrom uważa, że inteligencja ludzka, wspomagana przez technikę, nie będzie posiadała ograniczeń. Pojawia się wręcz oczekiwanie, że postczłowiek będzie prawdopodobnie w stanie odpowiedzieć na dotychczas nierozwiązane pytania filozoficzne czy też zrozumieć, opisać i bezbłędnie wyjaśnić dany mu świat: „W dodatku nasze mózgi mogą ograniczać nasze zdolności odkrywania prawd filozoficznych i naukowych prawd. Jest prawdopodobne, że pojawiające się w badaniach filozoficznych problemy z uzyskaniem solidnych i powszechnie akceptowalnych odpowiedzi na fundamentalne pytania mogą wynikać z faktu, że nie jesteśmy dość mądrzy, by w dziedzinie takich dociekań osiągnąć

22 N. Bostrom, The Transhumanist FAQ, Faculty of Philosophy, Oxford University 2003, s. 51.

23 M. More, A Letter to Mother Nature [w:] The Transhumanist Reader..., dz. cyt., s. 344.

24 http://www.newsweek.pl/ja--cyborg,69735,1,1.html - wywiad z Kevinem Warwickiem dotyczący dodatkowego zmysłu - echolokacji, który uzyskał poprzez implant zintegrowany z jego układem nerwowym [dostęp: 24.05.2015].

$25, \ldots$ just as is the case for the great apes, our own cognitive makeup may foreclose whole strata of understanding and mental activity. (...) The impossibility that I am referring to is more like the impossibility for us current humans to visualize an 200-dimensional hypersphere or to read, with perfect recollection and understanding, every book in the Library of Congress. These things are impossible for us because, simply put, we lack the brainpower.". N. Bostrom, Transhumanist Values [w:] Ethical Issues for the Twenty-first Century, art. cyt. 
sukces" 26. Postczłowiek ma być również istotą o rozwiniętej samokontroli, a co za tym idzie, będzie w stanie wpływać na własne emocje ${ }^{27}$. Emocje pozytywne, takie jak szczęście, zadowolenie, miłość itp. będzie mógł odczuwać w znacznie większym stopniu. Emocje negatywne, jak złość, nienawiść, zazdrość będą mogły zostać w znacznym stopniu przytłumione. Postczłowiek będzie w stanie samodzielnie - w zależności od potrzeb - wywoływać u siebie odpowiednie stany emocjonalne (np. stan ciągłego zadowolenia), dzięki czemu będzie mógł w pełni panować nad swym zachowaniem.

Ostatnią specyficzną „cechą” postczłowieka jest jego nieokreśloność fizyczna. Dla transhumanistów bardziej liczy się ostateczny skutek, tj. samo zaistnienie postczłowieka, a nie konkretny sposób, w jaki to nastąpi. Rachel Armstrong, jedna z badaczek transhumanizmu twierdzi przykładowo, że postczłowiek mógłby zaistnieć zarówno dzięki wykorzystaniu bioinżynierii, jak i dzięki ingerencji techniki $\mathrm{w}$ organizm ${ }^{28}$. Postczłowiek może więc być istotą z biologicznym ciałem, lecz zarazem posiadającą nadludzko rozwinięte zdolności (jak na przykład samoleczenie się) lub też cyborgiem, tj. robotem o humanoidalnej budowie, z biologicznymi funkcjami życiowymi. Nick Bostrom sugeruje, że postczłowiek może zaistnieć zarówno jako sztuczna inteligencja znajdująca się w np. komputerze, jak też jako cyborg, hologram czy android ${ }^{29}$. Transhumaniści twierdzą także, że nie ma powodu, by wszyscy postludzie mieli być tacy sami. Gdy się im pozostawi możliwość wyboru, może dojść do sytuacji, że cześć z nich będzie istniała jako zlepek informacji w Internecie, a cześć jako fizyczne cyborgi.

Postczłowiek będzie więc istotą doskonalszą od obecnego człowieka, ponieważ wszystkie cechy, którym przypisujemy pozytywną wartość, zostaną w nim ulepszone. Będzie dysponował inteligencją wyższą od naszej. Jego życie ulegnie wydłużeniu, stanie się odporny na choroby, epidemie oraz urazy. Trzeba podkreślić, że transhumaniści powiedzą, iż tego typu opis wcale nie jest fikcją. Sądzą, że taka wizja jest w zupełności realna oraz zasługująca na urzeczywistnienie. Twierdza również, że nie jest to wcale wizja czasowo odległa. „Trudno przewidzieć, jak długo zajmie wynalezienie odpowiednich technologii. Lądowanie na księżycu odbyło się wcześniej niż przewidywała większość ludzi [...]. Większość transhumanistów uważa, że superinteligencja i nanotechnologia zostaną opraco-

26 „Further, our human brains may cap our ability to discover philosophical and scientific truths. It is possible that failure of philosophical research to arrive at solid, generally accepted answers to many of the traditional big philosophical questions could be due to the fact that we are not smart enough to be successful in this kind of enquiry", tamże.

27 M. More, A Letter to Mother Nature [w:] The Transhumanist Reader..., wyd. cyt., s. 344.

28 R. Armstrong, Alternative Biologies [w:] The Transhumanist Reader..., wyd. cyt., s. 86-93.

29 Por. N. Bostrom, The Transhumanist FAQ..., wyd. cyt., ss. 14-20. 
wane w przeciągu 100 lat, cześć zaś uważa, że stanie się to w pierwszej tercji tego stulecia" 30 .

W transhumaniźmie mamy więc do czynienia z opisem przyszłości, który jest oparty na przewidywaniach wyprowadzonych z dotychczasowego rozwoju nauki i technologii. Jednak takie postrzeganie przez nich świata może łączyć się z błędem swoiście odczytywanego historycyzmu, o którym pisał Karl Popper. Po pierwsze, podstawowym błędem wydaje się założenie, że możliwe jest opracowanie ogólnych praw, które odnoszą się do całości ludzkich dziejów, podczas gdy poszczególne okresy historyczne charakteryzują się odmiennością; przyświecaja im inne cele i wartości. Po drugie, jeśli byłoby możliwe odkrycie praw rządzących historią, to w momencie gdy wysuniemy przewidywania co do kształtu „przyszłości”, mogą one okazać się niestosowalne. Przez to, że w momencie, gdy zaczniemy zmieniać teraźniejszość pod kątem tego, jaka będzie przyszłość, to wraz ze zmianą teraźniejszości ulegnie zmiana również przyszłość, sprawiając, że nasze przewidywania staną się fałszywe ${ }^{31}$. Możliwe są jeszcze inne wątpliwości. Wartości, które przyjmujemy obecnie, wcale nie musza być takie same w przyszłości, dlatego nie możemy mieć pewności, jak będzie wyglądał ludzki świat w przyszłości. „Stanie się postczłowiekiem oznacza przekroczenie limitów, które definiują mniej pożądane aspekty ludzkiej kondycji" 32 . Postludzie mają być istotami doskonalszymi od obecnego człowieka.

Zarazem transhumaniści podkreślają, że „[...] postludzie mogą kształtować siebie oraz własne środowisko na tak wiele nieznanych nam sposobów, że spekulacje na temat cech postludzi oraz postludzkiego świata są skazane na porażkę" 33 . Bostrom pisze, że problem ze zdefiniowaniem świata postludzkiego bierze się stąd, że brakuje nam wiedzy, jaką formę przybierze faktycznie postczłowiek. Jest to zarazem logiczna, jak i wymijająca odpowiedź. Gdy przyjmiemy, że postczłowiek zechce być zlepkiem informacji w sieci, to liczba serwerów i komputerów (i ich następców) będzie ogromna, a ingerencja w fizyczny świat będzie następowała

30 „It is often very hard to predict how long a certain technological development will take. The moon landing happened sooner than most people had expected... (...) The vast majority of transhumanists think that superintelligence and nanotechnology will both be developed in less than a hundred years, and many predict that it will happen well within the first third of this century". N. Bostrom, The Transhumanist FAQ..., wyd. cyt., s. 49.

31 Por. K. Popper, Nędza historycyzmu, przeł. Stefan Amsterdamski, Krąg, Warszawa 1989, ss. $24,48-61$.

32 „Becoming posthuman means exceeding the limitations that define the less desirable aspects of the „human condition"." M. More, The Philsophy of Transhumanism [w:] The Transhumanist Reader..., wyd. cyt., s. 16.

33 „Posthumans might shape themselves and their environment in so many new and profoundways that speculations about the detailed features of posthumans and the posthumanworld are likely to fail". N. Bostrom, The Transhumanist FAQ..., wyd. cyt., s. 6. 
np. za pomocą robotów. Jeśli natomiast ludzie przekształcą się w cyborgi, to w pewnych wymiarach świat przyszłości będzie podobny do świata teraźniejszego. Oba te scenariusze zawierają spełnienie postulatów transhumanistycznych. Transhumaniści sądzą, że ludzie przekształceni w takie istoty będą bardziej odporni na proces starzenia się, śmiertelność, i być może będą posiadali znacznie większe możliwości obcowania ze światem. Jeśli chodzi zaś o wartości świata posthumanistycznego, to transhumanizm mówi jedynie o „otwartym społeczeństwie” : „Ta zasada zaleca wspieranie ruchów społecznych, które wspierają wolność komunikacji, swobodę działania, eksperymenty, innowacje, krytycyzm i uczenie się. Sprzeciwianie się autorytarnej kontroli społecznej i niepotrzebnej hierarchii, sprzyjanie prawu i decentralizacji władzy i odpowiedzialności. Preferowanie negocjacji zamiast walki, wymiany ponad wymuszenia i komunikacji ponad przymus" 34 .

Choć tranhumaniści nie chcą sugerować, jak będzie wyglądał świat postludzki, to zarazem sądzą, że można tworzyć pewne modele tego przyszłego świata. Będzie to świat kreowany przez istoty znacznie inteligentniejsze od współczesnego człowieka, żyjące dłużej niż obecny człowiek, odporne na choroby, panujące nad swymi emocjami oraz posiadające więcej zmysłów niż człowiek „naturalny”. Takie opisy mogą skłaniać do wniosku, że w transhumaniźmie mamy do czynienia z utopią technologiczną w rozumieniu Mannheima (czyli faktyczną realizacją pewnej ideologii).

Trzeba jednak podkreślić, że sam Max More jest explicite przeciwny temu, by transhumanizm określać mianem utopii: „Częstość, z jaką krytycy transhumanizmu mówią o »doskonałych« ludziach, stanie perfekcji lub odnoszą się do utopijnego społeczeństwa sugeruje, że nie zaznajomili się dostatecznie z transhumanistyczną literaturą. Bardziej możliwe, że czytają ją z kognitywnymi klapkami na oczach, sprawiając, że nie rozumieją tego co czytają przez własne uprzedzenia" 35 . Definiowanie świata postludzkiego jako utopii (w sensie doskonałego stanu społecznego, jakkolwiek byśmy go rozumieli) jest zatem według More’a błędem. Po pierwsze, More twierdzi, że postczłowiek może realnie zaistnieć. Przy pewnym rozumieniu utopii, a dokładniej w rozumieniu Mannheima, utopie mogą być

34 ,That principle recommends ,supporting social orders that foster freedom of communication, freedom of action, experimentation, innovation, questioning, and learning. Opposing authoritarian social control and unnecessary hierarchy and favoring the rule of law and decentralization of power and responsibility. Preferring bargaining over battling, exchange over extortion, and communication over compulsion". [w:] M. More, The Philosophy of Transhumanism [w:] The Transhumanist Reader..., wyd. cyt., s. 16.

35 "The frequency with which critics talk of transhumanists as wanting to „perfect" human beings or to achieve a state of perfection or to bring about a utopian society suggests that they haven't actually read much transhumanist literature. More likely, they read it with cognitive blinders on, distorting what they read to fit their preconceptions" [w:] M. More, The Philosophy of Transhumanism [w:] The Transhumanist Reader..., dz. cyt., s. 23. 
jednak budowane w świecie rzeczywistym, za pomocą różnych technik socjologiczno-politycznych, przy wykorzystaniu dorobku nauki i techniki. Oznacza to, że dziś nie powinniśmy pytać, w jaki sposób utopie mogą zostać zrealizowane, tylko kiedy ${ }^{36}$. Po drugie, More twierdzi, że wizja świata postludzkiego nie jest utopijna, ponieważ nie postuluje budowy doskonałego świata, skończonego, statycznego, finalnego społeczeństwa, a sam postczłowiek będzie jedynie kolejnym etapem, a nie ostatecznym wytworem ewolucji gatunku ludzkiego. Ewolucja biologiczna potrzebowała milionów lat, by na świecie mógł się pojawić gatunek homo sapiens. Być może postczłowiek będzie pierwszym, który zaistnieje dzięki ewolucji biotechnologicznej, ale nie możemy a priori zakładać, że będzie również ostatnim.

Jeśli zdefiniujemy stan utopii jako stan doskonały, pozbawiony problemów społecznych czy politycznych, to nie możemy a priori założyć, że świat postczłowieka właśnie taki będzie. Dlatego More, krytykując tych, którzy nazywają świat postludzki utopią, konstruuje w zamian inny termin, który lepiej oddaje charakter transhumanistycznego świata. Tym terminem jest właśnie „ekstropia”. Sam termin został zdefiniowany w obecnym rozumieniu przez More'a w artykule Principles of Extropy ${ }^{37}$. More przedstawia w nim sześć postulatów ${ }^{38}$, które powinny być urzeczywistniane, jeżeli postczłowiek ma zaistnieć:

1) permanentny postęp;

2) „morfologiczna” wolność;

3) praktyczny optymizm;

4) inteligentna technika;

5) otwarte społeczeństwo;

6) racjonalne myślenie.

Ekstropia jest definiowana jest przez More'a w opozycji do tradycyjnego rozumienia utopii (związanej z dziełem Morusa). Jak pisze More, ekstropia to „otwartość na rozwój, a nie statyczna utopia. Ekstropia (ciągle oddalające się cele [postępu - przyp. K. Sz.] społeczeństwa) nad utopią (nie-miejscem)" 39 . More postrzega utopie jako konstrukcje jedynie teoretyczne (w czym widać podobieństwo do ideologicznego myślenia u Mannheima). Twierdzi, że ekstropia nie jest miejscem ani stanem doskonałości. „Nie implikuje to tego, że naszym celem jest

36 Jak pisał N. Bierdiajew: Utopie wydają się o wiele bliższe urzeczywistnienia, niż się dotychczas sądziło.

37 Por. M, More, Principles of Extropy (Version 3.11): An evolving framework of values and standards for continuously improving the human condition, http://lists.extropy.org/pipermail/ extropy-chat/2004-May/006399.html [dostęp 25.05.2015].

38 Tamże.

39 „Openness to improvement rather than a static utopia. Extropia (»ever-receding stretch goals for society «) over utopia (»no place«)." [w:] M. More, The Philosophy of Transhumanism [w:] The Transhumanist Reader..., wyd. cyt., s. 17. 
ostateczny, doskonały świat. Wręcz przeciwnie, koncepcja transhumanizmu opiera się na ekstropii - procesie nieustannego rozwoju, a nie statycznym stanie" ${ }^{40}$. Mimo że postludzie kreujący przyszłe społeczeństwo będą doskonalsi od ludzi, nie znaczy to - twierdzi More - że będą oni pozbawieni problemów. Wręcz przeciwnie, More przewiduje, że przyszłość będzie dla postludzi równie wielkim wyzwaniem, co dla współczesnych teraźniejszość. Problemy współczesności - takie jak głód, zmiany klimatyczne czy epidemie - mogą wprawdzie zostać rozwiązane, ale to nie oznacza, że przyszłość nie będzie pozbawiona wad ${ }^{41}$. Pojawią się prawdopodobnie nieznane nam zagrożenia i problemy, z którymi będzie musiał poradzić sobie postczłowiek. Ekstropia transhumanistów to fizyczny, psychiczny i intelektualny permanentny rozwój, a nie ostateczny, doskonały i skończony stan w rozwoju gatunku charakteryzowany jako utopia.

Jednym z kluczowych punktów w rozwoju transhumanizmu będzie pojawienie się możliwości „transferu umysłu”. Nick Bostrom pisze: „Twój mózg jest materialnym przedmiotem. Działanie materialnych przedmiotów opisują prawa fizyczne. Prawa fizyczne moga być odzwierciedlone w systemie operacyjnym. Czyli ludzki mózg może być odwzorowany w komputerze" 42 . Jeśli uda się sprowadzić człowieka do postaci cyfrowej na pewnym nośniku (np. na twardym dysku), dalszy rozwój będzie znacznie szybszy; mózg podłączony do komputera będzie mógł rozwiązywać problemy obecnie niemożliwe do rozwiązania, pozostając zarazem świadomym tych działań. Efektem może być uporanie się z najważniejszymi, niemożliwych obecnie do rozstrzygnięcia problemami ludzkości. Tego typu stan nazywany jest przez transhumanistów „technologiczną osobliwością" 43. Pojawienie się technologii transferu umysłu prawdopodobnie znacznie przyśpieszy rozwój ekstropii, ponieważ „świadomy” komputer może znacznie przyspieszyć postęp.

Współczesne komputery są w stanie wykonać miliardy obliczeń w krótkim czasie, jednak nie robią tego świadomie, ale są programowane przez użytkowników, czyli ich działanie wynika „z zewnątrz”, to znaczy, że człowiek jako istota świadoma, podejmuje decyzję oraz wyznacza działania, które wykonuje

40 „Nothing about this implies that the goal is to reach a final, perfect state. The contrary view is made explicit in the transhumanist concept of extropy - a process of perpetual progress, not a static state." M. More, The Philosophy of Transhumanism [w:] The Transhumanist Reader..., wyd. cyt., s. 23.

41 N. Bostrom, The Transhumanist FAQ..., wyd. cyt., s. 28.

42 „Your brain is a material object. The behavior of material objects is described by the laws of physics. The laws of physics can be modeled on a computer. Therefore, the behavior of your brain can be modeled on a computer." [w:] R. C. Merkle, Uploading [w:] The Transhumanist Reader..., wyd. cyt., s. 128.

43 Więcej na temat osobliwości przeczytać można w książce: R. Kurzweil, Nadchodzi osobliwość: kiedy czlowiek przekroczy granice biologii, przeł. Eliza Chodkowska, Anna Nowosielska, Kurhaus Publishing, Warszawa 2013. 
komputer. W przypadku wyposażenia komputera w świadomość, jego możliwości będą prawdopodobnie znacznie większe niż ludzi. Sprowadzenie świadomości człowieka do postaci cyfrowej, a następnie powielenie jej w internetowej „chmurze” sprawi, że człowiek zyska możliwość powielania siebie, zapewniając sobie bezpieczeństwo „przetrwania”. Będzie to oznaczało realizację kluczowego punktu transhumanizmu. To, czy później ludzie zostaną wprowadzeni do fizycznych awatarów, będzie zależeć od ich wyboru, właśnie ze względu na morfologiczną wolność.

Po tych opisach powstaje pytanie, czy transhumanistyczna ekstropia faktycznie różni się od utopii. Definicja ekstropii zaproponowana przez More'a jest przeciwieństwem utopii w tradycyjnym znaczeniu. To, co skończone i doskonałe, zostaje u More'a przeciwstawione temu, co nieskończone i niedoskonałe. Tradycyjna (związana z Morusem) definicja jest zbyt wąska, co jednak nie znaczy wcale, że koncepcja ekstropii nie ma charakteru utopijnego. Również w utopii opartej na koncepcji Mannheima zauważyć można krytykę zastanego stanu rzeczy. Transhumaniści nie tyle krytykują system społeczno-polityczny, jak to robił Morus, co krytykują stan rozwoju człowieka, jako istoty biologicznej. Jeśli odwołać się do definicji Mannheima, to można powiedzieć, że realizacja postulatów $\mathrm{H}+$ będzie oznaczała całkowitą przemianę ludzkiego świata. Ekstropia doprowadzi do wyłonienia się świata postludzkiego, czegoś różnego od tego, co znamy dzisiaj. Byłaby to zatem realizacja pewnego projektu zmiany zastanej rzeczywistości. Dlatego gdy transhumaniści podaja przybliżone parametry postludzkiego świata, to ekstropia, jako proces urzeczywistniania tych parametrów, nabiera charakteru utopii (rozumianej w duchu definicji Mannheima).

Według Pichta, utopia to stan poprawy ludzkiej rzeczywistości przy wykorzystaniu postępu naukowo-technologicznego, w celu zapewnienia gatunkowego przetrwania. Takie rozumienie utopii wydaje się zgodne z koncepcją More'a. To zaś oznacza, że ekstropia staje się utopią - w rozumieniu proponowanym przez Pichta. Może tu powstać zarzut - właśnie ze względu na to, że definicja staje się zbyt szeroka - że jakakolwiek poprawa warunków życiowych, np. rozwój GMO w rolnictwie, dzięki któremu następuje zwiększenie plonów, będzie również utopią; większa ilość pożywienia zapewni przecież przetrwanie większej liczbie ludzi, czyli szansa przetrwania gatunku zwiększa się. Przykładów tego typu jest mnóstwo, np. poduszka powietrzna w samochodzie, pasy bezpieczeństwa, coraz lepsze technologie recyklingu itp. Tego typu działania zwiększają biologiczną szanse przetrwania gatunku, czyli realizują założenia Pichta.

Ekstropia sama w sobie jest stanem ciągłego rozwoju jednostki i społeczeństwa. Powstaje zatem pytanie: czy ekstropia nie dokonywała się już wcześniej? Ludzkość rozwija się od wieków, między innymi za sprawą techniki. Liczba wynalazków oraz odkryć naukowych cięgle rośnie. Człowiek ulega historycznym przemianom, na przestrzeni wieków długość i jakość życia poprawia się, dostęp do 
wiedzy i informacji w dobie Internetu jest potencjalnie powszechny. Dlatego wydaje się, że można powiedzieć, że ekstropia to stan, który pojawił się wraz z pojawieniem się techniki.

Sądzę zatem, że transhumanistyczną ekstropię można uznać za utopię. Ekstropia jest co prawda procesem nieskończonym, ale zmiany w niej zachodzące będą prowadziły do urzeczywistnienia parametrów świata transhumanistycznego. Zmianie jakościowej ulegnie gatunek ludzki, który zostanie zastąpiony przez istoty doskonalsze. Dodatkowo, o ile w naturze końcem jednostki jest nieunikniona śmierć, to postczłowiek, zgodnie z poglądami transhumanistów, jest pozbawiony owej „biologicznej wady” (tak określają śmierć transhumanisci ${ }^{44}$ ). Jeśli uda się znacznie wydłużyć czas życia, będzie to realizacja jednego z najważniejszych „celów ewolucji", tj. trwania, choć w odniesieniu do jednostki, a nie całego gatunku. Niewyobrażalne wydłużenie życia człowieka, jak chcą tego transhumaniści, nie musi oznaczać końca ekstropijnego rozwoju, lecz będzie stopniową, nigdy nie zakończoną realizacją transhumanistycznej idei. Nie chcę popadać w spekulację, ale czy w momencie, gdyby ludzie z dnia na dzień przestali umierać z przyczyn naturalnych, czy w ludzkiej rzeczywistości nie zaszłaby pewna przełomowa zmiana? W moim osądzie: tak.

Nawet zakładając, że postczłowiek będzie umiał rozwiązać problemy naszego świata, to to nie oznacza, że rozwiąże on wszelkie możliwe kwestie, np. na gruncie filozofii. Postczłowiek może jawić się jako duch Pasterki z Dziadów Mickiewicza, która goniła za barankiem, ale nigdy nie udawało się jej osiągnąć celu. Możliwe jest również, że myślenie postczłowieka, który będzie posiadać dużo większe możliwości obliczeniowe, wspomagane przez technikę najnowszej generacji mogą przynieść inne rezultaty, co może również doprowadzić do gwałtownych przemian społecznych, politycznych, naukowych itp. Dzięki temu będzie się on w stanie udoskonalić, przez co jego wnioski staną się dokładniejsze, doskonalsze, co doprowadzi do kolejnej poprawy posthumanistycznego świata, i tak w nieskończoność. Będzie to zarazem ekstropia, czyli proces nieskończonego postępu, jak i utopia - w tym sensie (pochodzących od Mannheima), że będzie to stopniowe urzeczywistnianie pewnych idei.

Wydaje się zatem, że mówić o czymś jako o utopii można tylko z pewnego punktu widzenia i stanowiska historycznego. Jak pisze Mannheim: „Właśnie dlatego, że konkretne określenie utopijności następuje zawsze z określonego etapu rzeczywistości, możliwe jest to, że utopie dnia dzisiejszego mogą stać się rzeczywistością jutra" ${ }^{45}$. Jeszcze niedawno utopią dla człowiek było podróżowanie

44 M. More, A Letter to Mother Nature [w:] The Transhumanist Reader..., wyd. cyt., s. 344.

45 K. Mannheim, Ideologia i utopia..., wyd. cyt., s. 168. 
w kosmos; dziś pojawiają się prognozy budowy baz na Marsie czy Księżycu. Historia pokazuje, że przemiany zachodzą ciągle. Jako przykład można podać osoby, które były urodzone w Polsce przed wybuchem drugiej wojny światowej. Ich świat za każdym razem był inny: okres pokoju, okres drugiej wojny światowej, czasy komunizmu, i ostatecznie wolnej Polski. Przykłady te pokazują, że ekstropię można określić mianem utopii (w rozumieniu Mannheima).

Jednak tego rodzaju wyjaśnienie utopii zasadniczo modyfikuje jej dotychczasowe, tradycyjne rozumienie (w duchu koncepcji Morusa). Czy jednak utopia musi być stanem doskonałym? W Mieście słońca Campanelli nie zapomniano o wojsku czy lekarzach, co może świadczyć, że mogą zaistnieć pewne negatywne okoliczności jak wojna, czy też choroby ${ }^{46}$, które trzeba rozwiązać. Nie można więc myśleć, że utopia to miejsce pozbawione kłopotów, problemów. Tymczasem More sugeruje, że ekstropia transhumanistów nie będzie doskonała, lecz będą pojawiały się w niej różne problemy, przez co, jak sądzi, traci ona status utopii. Wydaje się jednak, że argumentacja More'a jest zasadna tylko wtedy, gdy wyjdziemy od monistycznego rozumienia samej utopii. Uwzględnienie definicji Mannheima pozbawia słuszności ocenę formułowaną przez More'a.

Krytyczne stanowisko wobec transhumanizmu zajmuje również Don Ihde, zarzucając mu, że tworzy przyszłą utopię. Don Ihde porównuje postulaty transhumanistów do „techno-fantasy szumu, który nosi znamiona magii” ${ }^{47}$. Przypomina również niegdysiejszy zachwyt naukowców nad technologią rozbijania atomu, która miała dać ludziom nieograniczone pokłady energii, co miało umożliwić rezygnację z eksploatacji Ziemi z surowców energetycznych. Jednakże technologia ta, miast zapewnić energię dla rozwoju całej ludzkości, skończyła się ponad 40-oma latami strachu przed użyciem broni atomowej.

Dodatkowo, jeśli przyjrzymy się założeniom transhumanizmu, postulują oni pewne warunki ${ }^{48}$, które powinny zostać spełnione przed tzw. „transformacją" człowieka. Są to następujące warunki:

1. zapewnienie bezpieczeństwa gatunkowi ludzkiemu (wykluczenie ryzyka wyginięcia);

2. bezwarunkowy i pozbawiony kontroli postęp technologiczny;

3. szeroki dostęp do technologii transhumanistycznych (bezwarunkowo dostępny każdemu człowiekowi na świecie).

46 T. Campanella, Miasto stońca, Alfa, Warszawa 1994, s. 53.

47 „Technofantasy hype is the current code for magic" [w:] Don Ihde, Of Which Human Are We Post? [w:] H+/-: Transhumanism and Its Critics, red. Gregory R. Hansell, William Grassie, Metanexus Institute, New York 2011, s. 57.

48 Por. N. Bostrom, Transhumanist Values [w:] Ethical Issue..., art. cyt. 
Jeśli spojrzymy krytycznie na postulaty formułowane przez Bostroma, one same noszą cechy utopijności, w tym znaczeniu, że mogą być bardzo trudne do spełnienia. Ilość środków potrzebnych do tego, by każdemu zapewnić możliwość przemiany w postczłowieka, musiałaby być ogromna. Co prawda, nie wiemy, jaką formę przybierze postczłowiek, lecz przypuszczalnie jego zaistnienie będzie wymagało ogromnych nakładów pracy. Biorąc pod uwagę, że postulowana przemiana miałaby nastąpić w skali całego gatunku, może się to okazać niemożliwe do urzeczywistnienia. Za kolejny z utopijnych postulatów można uznać postulat globalnego bezpieczeństwa ${ }^{49}$. Bostrom podkreśla, że gatunek ludzki narażony jest na różne katastrofy, np. katastrofy naturalne. Twierdzi zatem, że zapewnienie globalnego bezpieczeństwa, a więc np. likwidacja zagrożenia ze strony wojen na masową skalę, np. wojen atomowych. Jeśli udałoby się wyeliminować, lub być w stanie przeciwdziałać i zapobiegać większości katastrof zagrażającym ludzkości, osiągnięto by pewien stan doskonałości, spełniający znamiona utopii.

Podsumowując, utopia może być rozumiana na wiele, różnych sposobów, a na przestrzeni lat definicja ta nabrała wielu nowych znaczeń. Morus z utopii uczynił zagadkę językową (nawiązuje tu do rozumienia utopii jako eutopos i outopos miejsca dobrego i nierealnego). Różne próby interpretacji pojęcia utopii w kontekście dzieła Morusa sprawiły, że samo pojęcie utopii nabrało wielu znaczeń. Picht i Mannheim definiują pojęcie utopii szerzej, niż się tradycyjnie przyjmuje, tj. jako zmianę zachodzącą w rzeczywistości, a nie statyczny i doskonały stan. Dodatkowo, jak dowodzą analizy J. Szackiego, utopia nie musi być miejscem statycznym oraz doskonałym. Może być umieszczana w czasie, przestrzeni czy w oderwaniu od zastanej rzeczywistości. Definiując ekstropię jako przeciwieństwo utopii, More próbuje zapobiec nazywaniu świata postludzkiego światem utopijnym. Wielość możliwych sensów utopia sprawia jednak, że zabieg ten, choć przemyślany i celowy, nie jest w pełni udany. Sądzę, że w przypadku realizacji swych postulatów transhumanizm przekształci się w utopię, gdyż dotychczasowy świat ulegnie całkowitej przebudowie. Morus stworzył swoją Utopie jako krytykę ówczesnego stanu społeczno-politycznego. Formułując swoje postulaty, transhumaniści krytykują niedoskonałości człowieka. Z tego względu szeroko rozumiany transhumanizm może być uznana za utopię.

49 J. Zdybel, Darwinizm spoleczny a kryzys optymizmu historycznego [w:] W kregu pesymizmu historycznego, red. Zdzisław J. Czarnecki, Wydawnictwo Uniwersytetu Marii Curie-Skłodowskiej, Lublin 1992, ss. 165-178. 


\section{Transhumanism: utopia or extropy?}

\section{Summary}

This paper compares the concept of utopia and the concept of extropy - an important category associated with the transhumanist thought. Extropy is understood by transhumanists as a continuous progress, constantly retreating development. Such a definition of extropy, formulated by Max More, stands in opposition to the traditional understanding of utopia, but with closer inspection of transhumanizm, it turns out that we are probably dealing with a technological utopia. Therefore, first we must redefine the concept of utopia, and then confront it with the transhumanist concept of posthuman. I try to show that even though extropy stands in opposition to the traditional definition of utopia, we could see some common elements in both of them.

Key words: utopia, extropy, transhumanism, posthuman, Max More, Thomas More, Karl Mannheim, Georg Picht

Słowa kluczowe: utopia, ekstropia, transhumanizm, postczłowiek, Max More, Tomasz Morus, Karl Mannheim, Georg Picht

\section{Bibliografia}

Armstrong Rachel, Alternative Biologies [w:] The Transhumanist Reader: Classical and Contemporary Essays on the Science, Technology, and Philosophy of the Human Future, red. Max More, Natasha Vita-More, Wiley-Blackwell, Chichester UK 2013, ss. 86-93.

Blackford Rusell, The Great Transition [w:] The Transhumanist Reader: Classical and Contemporary Essays on the Science, Technology, and Philosophy of the Human Future, red. Max More, Natasha Vita-More, Wiley-Blackwell, Chichester UK 2013, ss. 322-328.

Bostrom Nick, The Transhumanist FAQ, Faculty of Philosophy, Oxford University 2003, http://www.nickbostrom.com/views/transhumanist.pdf [dostęp: 24.05.2015].

Bostrom Nick, Transhumanist Values [w:] Ethical Issues for the Twenty-first Century, red. Frederick Adams, Philosophy Documentation Center, Charlottesville 2005, ss. $3-14$.

Campanella Tommaso, Miasto słońca, przeł. L. i R. Brandwajnowie, Alfa, Warszawa 1994.

Don Ihde, Of Which Human Are We Post? [w:] H+/-: Transhumanism and Its Critics, red. Gregory R. Hansell, William Grassie, Metanexus Institute, New York 2011, ss. $56-61$.

Huxley Aldous, Nowy wspaniaty świat, przeł. Bogdan Baran, Warszawskie Wydawnictwo Literackie Muza, Warszawa 2014. 
Kurzweil Ray, Nadchodzi osobliwość: kiedy człowiek przekroczy granice biologii, przeł. Eliza Chodkowska, Anna Nowosielska, Kurhaus Publishing, Warszawa 2013.

Mannheim Karl, Ideologia i utopia, przeł. Jan Miziński, Test, Lublin 1992.

Merkle Ralph C., Uploading [w:] The Transhumanist Reader: Classical and Contemporary Essays on the Science, Technology, and Philosophy of the Human Future, red. Max More, Natasha Vita-More, Wiley-Blackwell, Chichester UK 2013, ss. $128-133$.

More Max, A Letter to Mother Nature [w:] The Transhumanist Reader: Classical and Contemporary Essays on the Science, Technology, and Philosophy of the Human Future, red. Max More, Natasha Vita-More, Wiley-Blackwell, Chichester UK 2013, ss. 344-345.

More Max, The Philosophy of Transhumanism [w:] The Transhumanist Reader: Classical and Contemporary Essays on the Science, Technology, and Philosophy of the Human Future, red. Max More, Natasha Vita-More, Wiley-Blackwell, Chichester UK 2013, ss. 15-25.

Morus Tomasz, Utopia, przeł. Barbara Smoczyńska, Daimonion, Lublin 1993.

Orwell George, Rok 1984, przeł. Tomasz Mirkowicz, Warszawskie Wydawnictwo Literackie Muza, Warszawa 2013.

Picht Georg, Technika i utopia [w:] Tenże, Odwaga utopii, przeł. Krzysztof Maurin, Krzysztof Michalski, Krzysztof Wolicki, Państwowy Instytut Wydawniczy, Warszawa 1981, ss. 188-208.

Popper Karl, Nędza historycyzmu, przeł. Stefan Amsterdamski, Krąg, Warszawa 1989.

Ricœur Paul, Lectures on Ideology and Utopia, Columbia University Press, New York 1986.

Szacki Jerzy, Spotkania z utopia, Sic!, Warszawa 2000.

Szymański Kamil, Tranhsumanizm, „Kultura i Wartości”, 13/2015, ss. 133-152 [dostęp: 05.07.2015].

Zdybel Jolanta, Darwinizm spoleczny a kryzys optymizmu historycznego [w:] W kregu pesymizmu historycznego, red. Zdzisław J. Czarnecki, Wydawnictwo Uniwersytetu Marii Curie-Skłodowskiej, Lublin 1992, ss. 165-178.

PEF, Hasło: Utopia http://www.ptta.pl/pef/pdf/u/utopia.pdf [dostęp: 23.05.2015]

http://www.newsweek.pl/ja--cyborg,69735,1,1.html Wywiad z K. Warwick [dostęp: 24. 05.2015]

http://www.businessinsider.com/les-baugh-is-the-first-person-with-two-mind-controlled -robotic-arms-2014-12 Les Baugh - mężczyzna który posiada protezy rąk zintegrowane z jego systemem nerwowym [dostęp: 24.05.2015]

http://www.kurzweilai.net/robotic-leg-prosthetic-allows-amputees-to-walk-normally Przykładowe informacje na temat zaawansowanych protez [dostęp: 24.05.2015] 